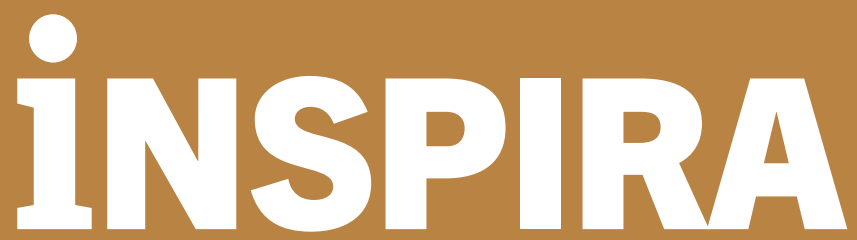

Tidsskrift for anestesi-, operasjon- og intensivsykepleiere

Forskningsartikler | Vol. 16, No. 2, 2021, s. 20-33

\title{
Oversettelse og krysskulturell tilpasning av «The ISBAR handover tool»
}

\author{
Mats A. Kinn-Mikalsen \\ Intensivsykepleier, MNSc, Intensivavdelingen, Sykehuset Østfold, Kalnes \\ E-post: matskinnmikalsen@gmail.com

\section{Linda Skaug Tangvik} \\ Intensivsykepleier, MNSc, Medisinsk intensiv postoperativ, Haraldsplass Diakonale Sykehus, Bergen
}

\section{Tone Johnsgaard}

Høgskolelektor, intensivsykepleier, MSc, Høgskulen på Vestlandet, Institutt for helse- og omsorgsvitskap, Bergen

\section{Marit Hegg Reime}

Førstelektor, Cand.polit., Høgskulen på Vestlandet, Institutt for helse- og omsorgsvitskap, Bergen

\section{Sammendrag}

Bakgrunn: Overlevering av pasientansvar innebærer en risiko for at betydningsfull informasjon ikke blir videreført til neste ledd, noe som kan svekke pasientsikkerheten. Verdens helseorganisasjon anbefaler kommunikasjonsverktøyet ISBAR (identifikasjon, situasjon, bakgrunn, aktuell status og råd) som en standard ved overlevering av pasientinformasjon. I 2017 besluttet Helsedirektoratet at ISBAR skal innføres i det norske helsevesenet gjennom pasientsikkerhetskampanjen «I trygge hender 24/7». I forbindelse med implementering av ISBAR på et norsk sykehus ble det australske spørreskjemaet «The ISBAR handover tool» oversatt og kulturelt tilpasset for å kunne unders $\varnothing$ ke den muntlige overleveringen av pasientinformasjon mellom en intensivavdeling og medisinske sengeposter.

Hensikt: $\AA$ presentere oversettelsesprosedyren og den kulturelle tilpasningen av spørreskjemaet «The ISBAR handover tool» til bruk i en norsk kontekst.

Metode: Med tillatelse fra utviklerne ble spørreskjemaet oversatt til norsk med utgangspunkt i Beatons seks trinn for oversettelse av spørreskjema: frem-oversettelse, syntese, tilbake-oversettelse, ekspertkomite, pretest og dokumentasjon av oversettelsesprosess til utviklerne av spørreskjemaet. Spørreskjemaet er tilpasset bruk ved intrahospitale overflyttinger av pasienter. Baselineskjemaet inneholder 8 lukkede spørsmål og 1 åpent spørsmål, og posttestskjemaet inneholder 12 lukkede spørsmål og 2 åpne spørsmål. 
Resultat: Ekspertkomiteen kom frem til konsensus om lingvistisk og kulturelt innhold i den norske versjonen av spørreskjemaet. Vi erfarte at bruk av oversetter som også har helsefaglig bakgrunn var gunstig for å løse lingvistiske og kulturelle utfordringer i oversettelsesprosessen.

Konklusjon: Vi har synliggjort oversettelsesprosessen og hvilke lingvistiske og kulturelle utfordringer vi st $\varnothing$ tte på i oversettelsen av spørreskjemaet «The ISBAR handover tool» til norsk. Spørreskjemaet er tilpasset bruk ved intrahospitale overflyttinger og kartlegger hvordan muntlige overflyttingsrapporter oppfattes før og etter implementering av ISBAR kommunikasjonsverkt $\varnothing \mathrm{y}$. Det gjenstår å teste spørreskjemaets psykometriske egenskaper.

Nøkkelord: oversettelsesprosess; tverrkulturell validitet; ISBAR; pasientoverføring; intrahospitale overflyttinger; pasientsikkerhet

\section{Abstract}

\section{Translation and cross-cultural validation of the questionaire "The ISBAR} handover tool"

Background: Patient handover entails a risk that important information will not be passed on, which may be a threat to patient safety. The World Health Organization recommends the ISBAR communication and handover tool to increase patient safety. In 2017, the Norwegian Directorate of Health decided that the ISBAR communication tool should be implemented in the Norwegian healthcare system through the patient safety program "In safe hands $24 / 7$ ". Before implementation of ISBAR in a Norwegian hospital, the Australian questionnaire "The ISBAR handover tool" was translated and culturally adapted in order to investigate the nurses verbal handover of information about the patient between an intensive care unit and medical wards.

Aim: To present the translation procedure and the cross-cultural validation of the questionnaire “The ISBAR handover tool” for use in a Norwegian context.

Method: With permission from the developers, the questionnaire was translated into Norwegian based on Beatons six steps for translation of questionnaires; forward translation, synthesis, back translation, expert committee, pretest and documentation of the translation process to the developers of the questionnaire. The questionnaire is adapted for use in intrahospital transfers of patients. The baseline form contains 8 closed questions and one open question, and the posttest form contains 12 closed questions and 2 open questions.

Result: The committee of experts reached a consensus on the linguistic and cultural content of the Norwegian version of the questionnaire. We experienced that the use of a translator who also had a background as a health professional was beneficial for solving linguistic and cultural challenges in the translation process.

Conclusion: We have visualized the translation process and the linguistic and cultural challenges we encountered in translating the questionnaire "The ISBAR handover tool" into Norwegian. The questionnaire is adapted for use in intrahospital transfers and charts how verbal transfer reports are perceived before and after implementation of the ISBAR communication tool. Further, there is a need to test the psychometric properties of the questionnaire.

Keywords: Translation process, cross-cultural validity, ISBAR, patient handover, intrahospital transfers, patient safety

\section{Introduksjon}

Overlevering av pasientansvar innebærer en risiko for at betydningsfull informasjon ikke blir videreført til neste ledd, noe som kan svekke pasientsikkerheten (1). I 2018 kom den siste publiserte årsrapporten fra «Meldeordningen for uønskede hendelser 
i spesialisthelsetjenesten». Den viste at 317 uønskede hendelser ble rapportert i forbindelse med overføring av pasientansvar ved innleggelse eller internt på norske sykehus (2). Ellers i verden er pasientoverleveringer på topp-fem-listen for områder som fører til uønskede pasienthendelser og unødvendige helseutgifter (3). Intensivavdelinger opplever på grunn av sin mangfoldige funksjon overflytting av pasienter fra akuttmottak, operasjonsavdelinger og medisinske- og kirurgiske sengeposter (4). Imidlertid beskrives innholdet i de intrahospitale muntlige overflyttingsrapportene som mangelfulle og ustrukturerte (5), og oppsummert forskning uttrykker behov for forbedringer og en standardisering av intrahospitale overflyttingsrapporter $(6,7)$.

Kommunikasjonsverktøyet ISBAR (identifikasjon, situasjon, bakgrunn, aktuell status og råd) er utformet for å gi en strukturert og effektiv rapport ved pasientoverlevering mellom helsepersonell (8). ISBAR ble utarbeidet av det amerikanske forsvaret som et verktøy for å bidra til å standardisere og sikre effektiv kommunikasjon i kritiske situasjoner, og ble ansett som så velfungerende at det på 2000-tallet ble implementert i helsevesenet, først i USA og senere også i andre deler av verden $(5,9)$. I 2007 kom Verdens helseorganisasjon (WHO) med en anbefaling om bruk av ISBAR som en standardisert tilnærming ved pasientoverleveringer (10). Kommunikasjonsverktøyet ISBAR har fra 2017 og utover blitt innført på flere norske sykehus som en del av tiltakspakken «Tidlig oppdagelse av forverret tilstand» (11). ISBAR blir i denne sammenheng brukt som et kommunikasjonsverktøy i en algoritme for å oppdage endringer i pasientens tilstand så tidlig som mulig og iverksette relevante tiltak. I denne algoritmen blir ISBAR forventet anvendt når man skal kontakte lege og/eller gi rapport ved overlevering av pasientansvar. For å bidra til presise beskrivelser av endringer i pasientens tilstand, anbefales i denne sammenheng bruk av NEWS2 (national early warning score) (11).

I forbindelse med implementering av ISBAR på et norsk sykehus i 2018 (12), trengte vi et verkt $\varnothing y$ for å kunne unders $\varnothing$ ke den muntlige overleveringen av pasientinformasjon ved intrahospitale overflyttinger før og etter implementering av ISBAR. Vi fant at spørreskjemaet «The ISBAR handover tool» var anvendbart til dette formålet, og valgte å oversette og kulturelt tilpasse spørreskjemaet til bruk i en norsk kontekst. Tverrkulturell validitet unders $\varnothing$ ker om en oversatt versjon av et spørreskjema fungerer på samme måte som den originale versjonen. I henhold til COSMIN («consensus-based standards for the selection of health measurement instruments») er oversettelsesprosessen en del av måleegenskapen tverrkulturell validitet (13). For å kunne vurdere den tverrkulturelle validiteten er det derfor viktig å synliggjøre selve oversettelsesprosessen, og i hvilken grad den følger internasjonale retningslinjer for frem- og tilbakeoversettelse (14).

\section{Hensikt}

Hensikten med denne metodeartikkelen er å presentere oversettelsesprosedyren og den kulturelle tilpasningen av spørreskjemaet «The ISBAR handover tool». Spørreskjemaet er egnet for studier der ISBAR skal implementeres som kommunikasjonsverktøy, da det 
består av et baselineskjema og et posttestskjema som gir muligheter for sammenligning i et pre-post-design. Artikkelen inngår som del i en implementeringsstudie av ISBAR på et norsk sykehus.

\section{Metode}

Vi benyttet Beaton (15) sin metode for frem- og tilbake-oversettelse i denne studien. I det følgende gjør vi rede for spørreskjemaets innhold og prosedyren som er benyttet for oversettelse og krysskulturell tilpasning.

\section{Spørreskjemaet}

Spørreskjemaet «The ISBAR handover tool» ble utviklet av Thompson og medarbeidere (16) for å kartlegge overlevering av pasientinformasjon mellom turnusleger på et sykehus i Australia, før og etter implementering av ISBAR. Instrumentutviklerne ga på forespørsel tillatelse til å oversette spørreskjemaet til norsk. Baselineskjemaet inneholder 8 lukkede spørsmål og 1 åpent spørsmål (tabell 2). De lukkede spørsmålene kartlegger om systemet for muntlig overlevering er tidseffektivt, om det er likt for alle pasienter, om det gir tilstrekkelig informasjon om pasienten, om det har god eller dårlig struktur, om det formidler pasientens tilstand slik at tilstanden stemmer med det kliniske bildet, og om en ut fra overleveringen av pasientinformasjon føler seg trygg på å overta ansvaret for pasienten. Det åpne spørsmålet etterspør hvordan den muntlige overleveringsrapporten kan forbedres. Posttestskjemaet inneholder 11 lukkede spørsmål og 2 åpne spørsmål (tabell 3). Posttesten kartlegger om opplæring og bruk av ISBAR har forbedret den muntlige rapporten, om verktøyet er anvendelig, om ISBAR har forbedret pasientbehandling og pasientsikkerhet og om undervisning om ISBAR har styrket ferdigheter og selvtillit i å gi muntlig rapport. De åpne spørsmålene etterspør hvordan ISBAR enten har forbedret eller forverret den muntlige overleveringsrapporten og hvordan rapporten kan forbedres. Baselineskjemaet og posttestskjemaet har 7 spørsmål som er identiske, nummer 1-5, 7 og 8, noe som gir mulighet for å sammenligne resultatet før og etter implementering av ISBAR. Respondentene angir sine svar på påstandene som fremsettes på en sekspunkts Likert-skala, der svaralternativene varierer fra «svært enig» til «svært uenig».

\section{Oversettelse av sporreskjemaet}

Ved oversettelse av spørreskjema fra et språk til et annet er det viktig å følge noen essensielle steg i en frem- og tilbake-oversettelse (14). Det er ikke tilstrekkelig med en direkte oversettelse av teksten, teksten må også tilpasses kulturen spørreskjemaet skal brukes i for at den skal ha et meningsinnhold som er forståelig. Vi har fulgt Beatons (15) seks trinn for oversettelse (figur 1). Trinn 1 var å oversette fra originalspråket til norsk. Dette bør gjøres av noen med målspråket, altså norsk, som sitt morsmål. 
Beaton anbefaler at minst to personer gjør denne frem-oversettelsen, og de bør ha ulik bakgrunn. På denne måten kan en sammenligne diskrepanser mellom oversettelsene og få frem nyanser i språket. I vår frem-oversettelse var det fire personer som uavhengig av hverandre oversatte én versjon hver. Alle hadde norsk som morsmål, snakket og forstod engelsk språk godt, og hadde bakgrunn fra ulike deler av helsetjenesten og fra høyere utdanningsinstitusjoner. Hensikten med frem-oversettelsen var å sørge for at skjemaet var forståelig på norsk og tilpasset konteksten spørreskjemaet skulle brukes i. Trinn 2 var å syntetisere de ulike oversettelsene. Her diskuterte oversetterne og forskergruppen seg frem til en versjon det var konsensus om. Trinn 3 var å oversette spørreskjemaet det var konsensus om tilbake til originalspråket. Dette skal gjøres av minimum to personer som har originalspråket som sitt morsmål, i dette tilfellet engelsk. Disse personene skal ikke se originalversjonen eller være orientert om hvilke begreper som undersøkes, og skal kun være eksperter på selve språket. To oversettere, hvorav én hadde helsefaglig bakgrunn, gjennomførte tilbake-oversettelsen. Dette trinnet er en prosess for å sjekke skjemaets validitet og sikre at den oversatte versjonen reflekterer det samme innholdet som originalversjonen. Trinn 4 var å opprette en ekspertkomite for å vurdere og bidra til tverrkulturell tilpasning av skjemaet.

Ekspertkomiteen bestod av to forskere, to sykepleiere som var eksperter på bruken av ISBAR i praksisfeltet, to sykepleielærere som bruker ISBAR i ferdighetstrening og simulering, to frem-oversettere og en tilbake-oversetter. I denne fasen hadde ekspertkomiteen dialog med utviklerne av spørreskjemaet per mail og fikk tilbakemeldinger på tilbake-oversettelsen. Ekspertkomiteen gikk gjennom resultatene fra alle de foregående trinnene og diskuterte om begrepene i teksten betydde det samme (semantic equivalence), om en må bruke nye ord (idiomatic equivalence; experiential equivalence) og om ordene har ulik mening mellom de to kulturene (conceptual equivalence) (15). Ekspertkomiteen utformet nå et utkast til den norske versjonen av spørreskjemaet. Trinn 5 var å teste ut spørreskjemaet, og Beaton (14) anbefaler at dette ideelt sett bør gjøres på 30-40 personer. Vi testet umiddelbar validitet og innholdsvaliditet for den norske versjonen av spørreskjemaet på åtte nyutdannede intensivsykepleiere. De åtte som ble spurt om å bidra fikk spørreskjemaet tilsendt, og gav tilbakemeldinger per mail på om uttalelsene i spørreskjemaene var tydelige og forståelige på norsk og om skjemaet målte det som det var tiltenkt å måle. De vurderte også om svaralternativene var i samsvar med originalskjemaet. Trinn 6 var å dokumentere oversettelsesprosessen for utviklerne av skjemaet. Tabell 1 viser kommentarer fra utviklerne på tilbake-oversettelsen for noen begreper som endret seg ved kulturell tilpasning. Vi hadde korrespondanse per mail for å forklare den norske betydningen av disse begrepene. Ved oversettelse til et annet språk og en annen kultur er det viktigere å beholde samme meningsinnhold fremfor den direkte lingvistiske oversettelsen (15). Tabell 1 viser eksempel på direkte oversettelse og kulturell tilpasning til en norsk kontekst for noen av begrepene i spørreskjemaet. 


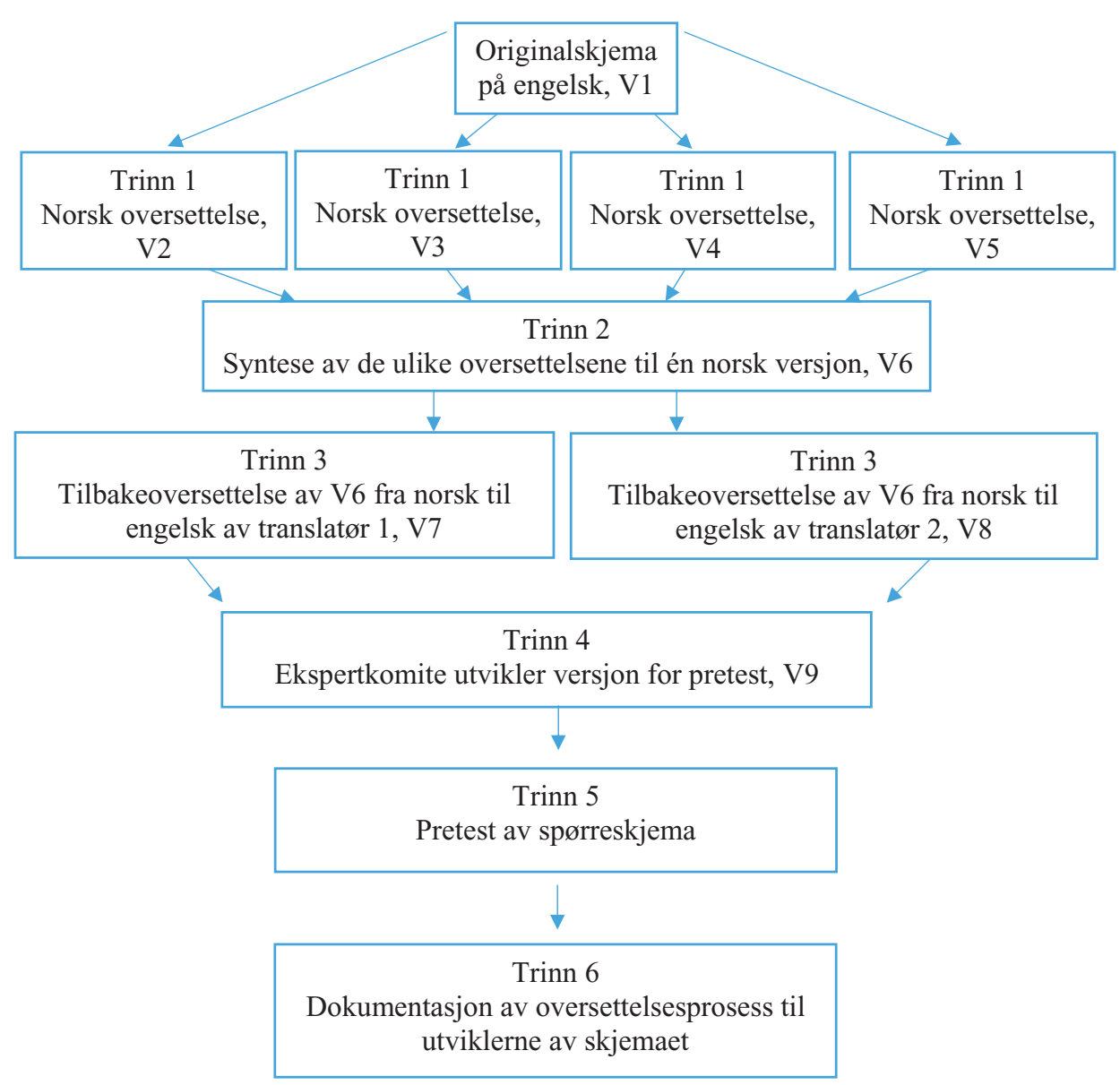

Figur 1 Trinn i oversettelsesprosessen i henhold til Beaton sin modell (15)

\section{Forskningsetikk}

Studien er godkjent av Norsk senter for forskningsdata (NSD) - prosjektnummer 57512.

\section{Resultater}

Umiddelbar validering og innholdsvalidering som ble utført av de åtte nyutdannede intensivsykepleierne resulterte i noen mindre justeringer. Basert på tilbakemeldingene ble det besluttet at det skulle legges til en avklaring i den norske versjonen av posttestskjemaets spørsmål 3: om man, dersom man skåret 3 eller mindre, følte at man fikk for lite eller for mye informasjon. Sykepleierne gav også tilbakemelding om at det i vår kontekst var mer riktig å bruke begrepet 'anvendelig' i stedet for 'bærekraftig' for begrepet 'sustainable' i spørsmål 9 i den norske versjonen av posttestskjemaet.

Utviklerne av spørreskjemaet hadde kommentarer til to begreper som endret seg ved tilbake-oversettelsen. Dette var oversettelse av begrepene 'urgent attention' og 'sustainable' (tabell 1). Vi diskuterte tilbakemeldingene fra utviklerne med ekspertkomiteen og kom frem til at den norske versjonen hadde det samme meningsinnholdet som originalskjemaet. I den norske versjonen av spørreskjemaet ble det lagt til et oppfølgingsspørsmål under spørsmål nr. 3 (tabell 2 og 3), da vi ønsket å finne svar på om 


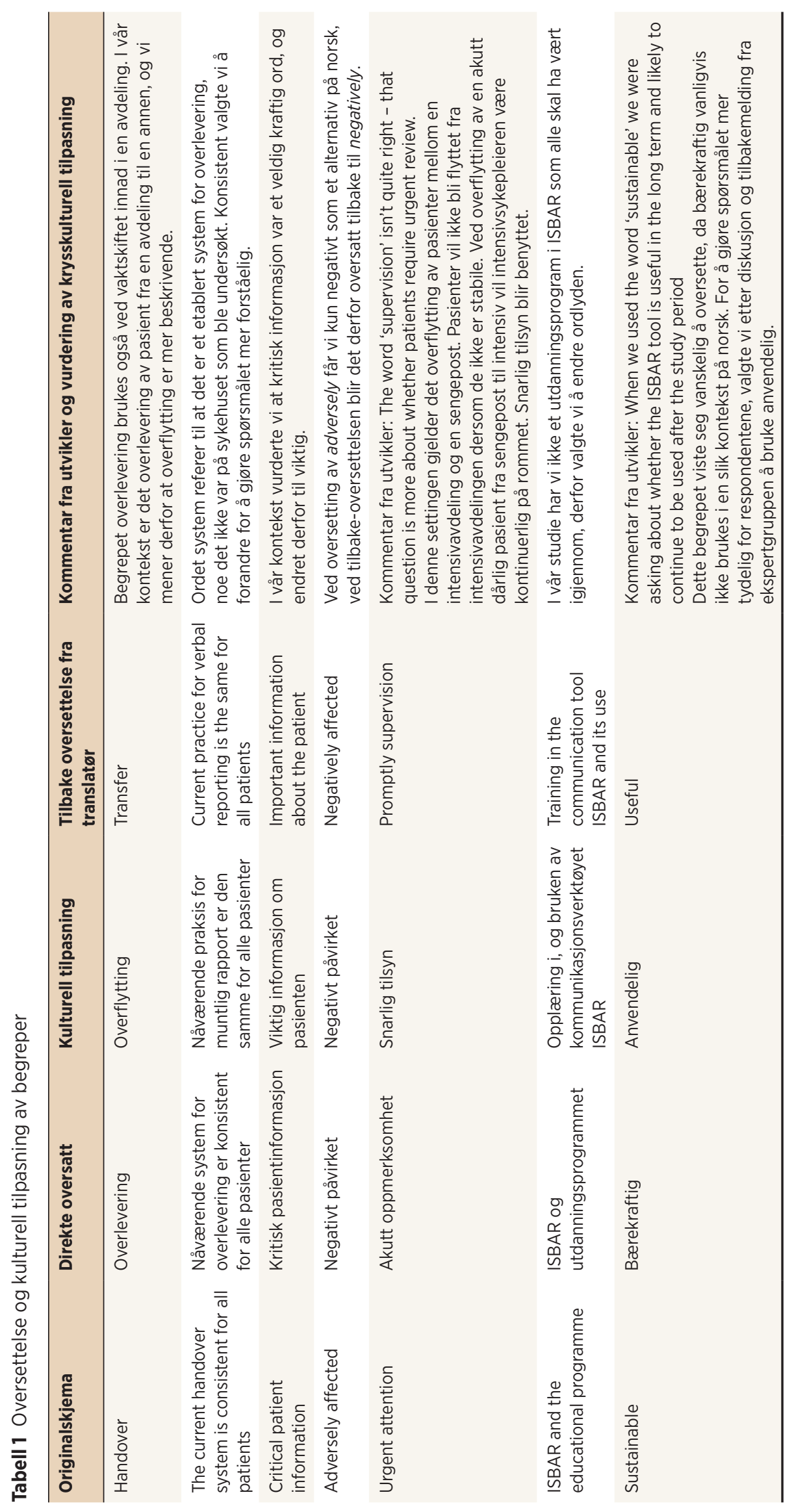




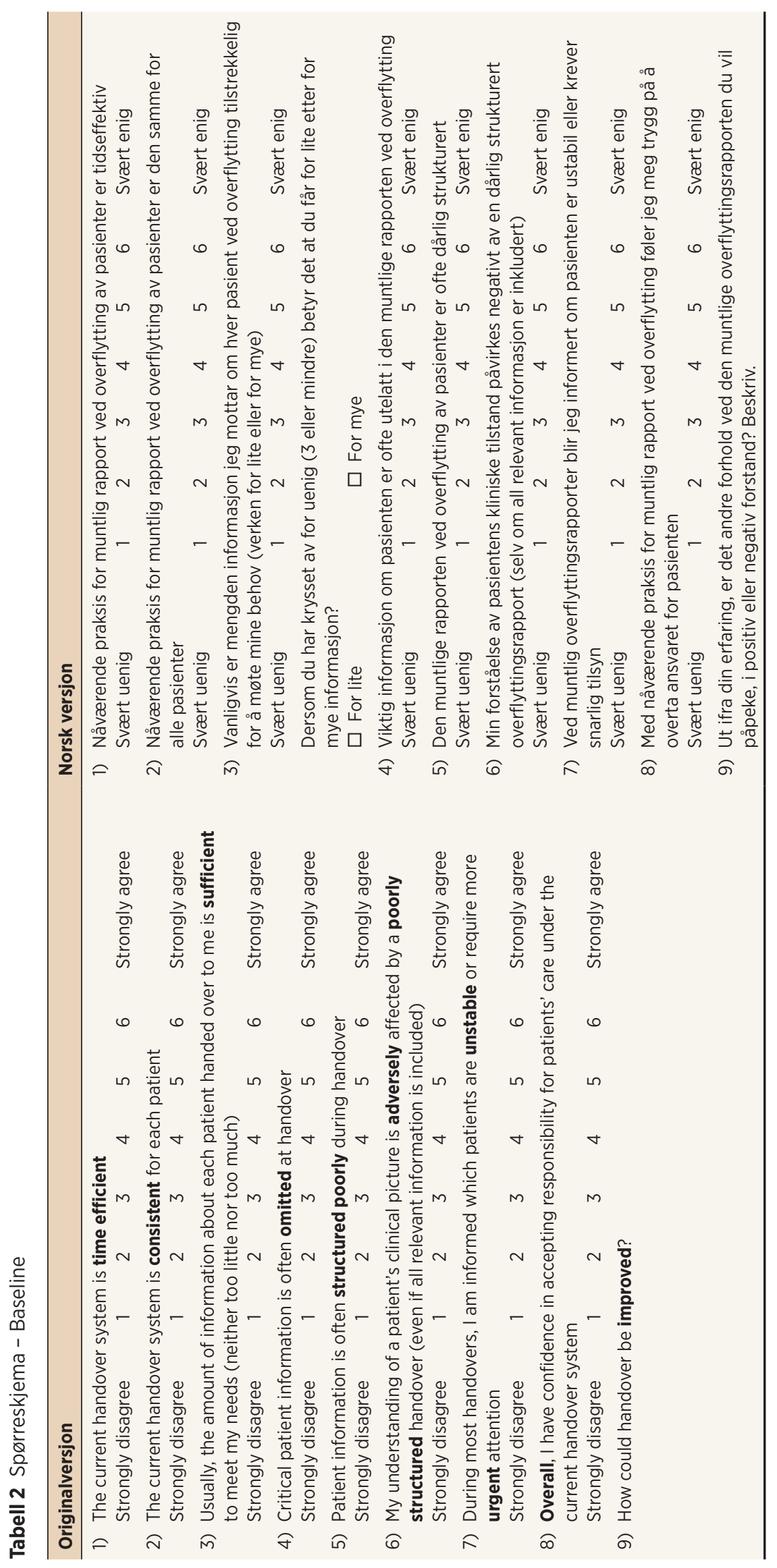




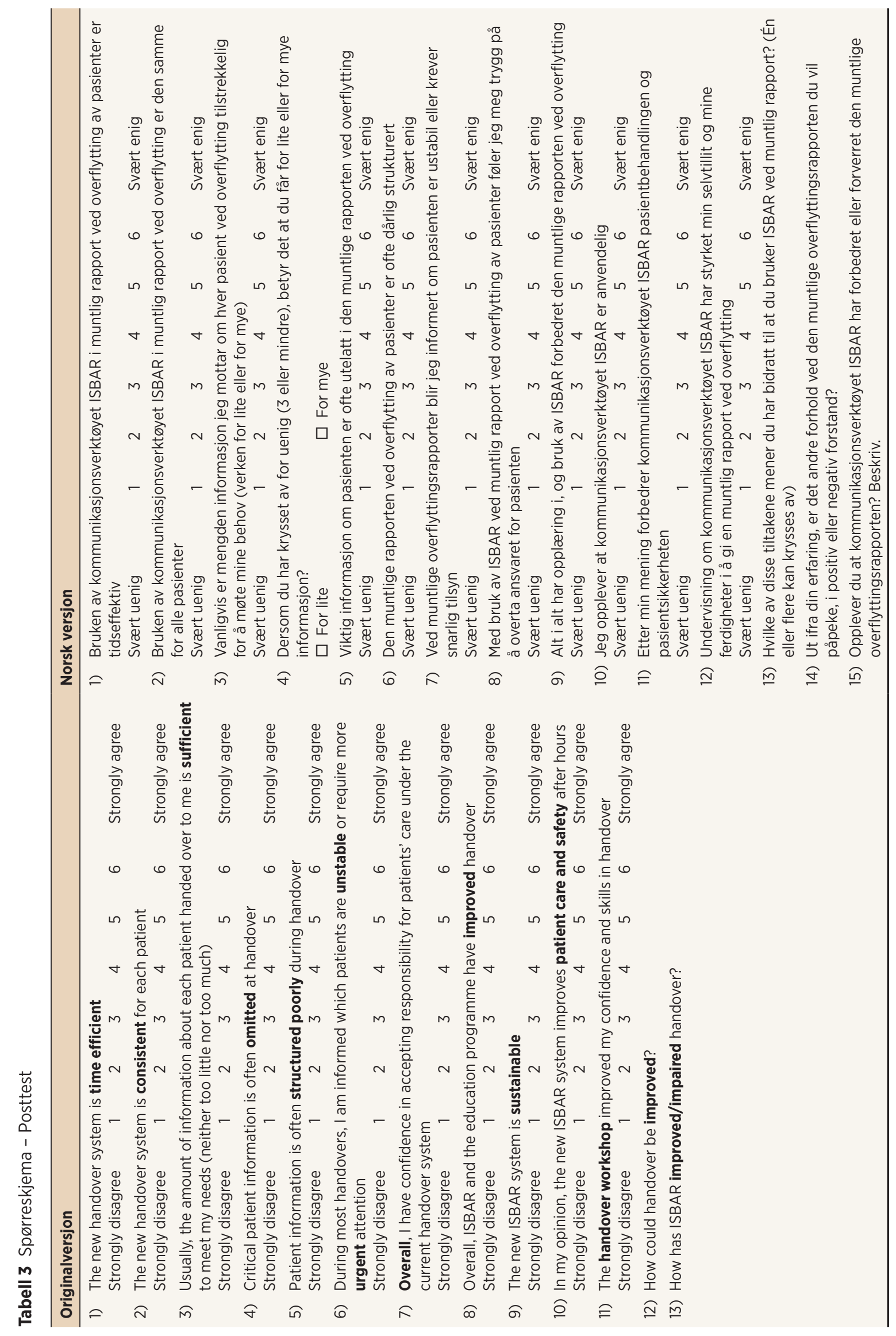


respondentene erfarte at de får for lite eller for mye informasjon ved muntlig rapport. Grunnen til at vi ønsket denne presiseringen var at tidligere forskning har funnet at sykepleiere på intensivavdelinger og sykepleiere på sengeposter har ulike oppfatninger om hva som bør inngå i den muntlige overflyttingsrapporten $(8,17)$.

Den norske versjonen av posttestskjemaet ble utvidet med ett spørsmål (spm. 12), som omhandlet hvilke implementeringsstrategier som var mest vellykket ved implementering av ISBAR kommunikasjonsverktøy for sikker kommunikasjon. De to åpne spørsmålene i samme skjema (spm. 13 og spm. 14) ble modifisert for å være mer nøytrale når en innhentet sykepleiernes erfaringer med bruk av ISBAR, ettersom vi vurderte at spørsmålene slik de var formulert i originalskjemaet kunne påvirke sykepleierne til å svare kort i stedet for å utdype.

\section{Diskusjon}

Kulturell tilpasning, også kalt tverrkulturell validitet, anses som relevant for spørreskjemaer som har blitt oversatt eller modifisert for bruk i en annen kulturell gruppe enn det originale spørreskjemaet (18). Kvaliteten på oversettelsen og validering av det oversatte spørreskjemaet spiller en viktig rolle for å sikre at resultatene oppnådd i tverrkulturell forskning ikke skyldes feil i oversettelsen, men snarere skyldes reelle forskjeller eller likheter mellom kulturer i forhold til fenomenene som måles (19,20). Funn fra en litteraturoversikt som har studert hvordan oversettelsesprosedyrer og kulturell tilpasning er beskrevet i forskningsartikler, viste at det var stor variasjon i oversetternes kvalifikasjoner og at det var mangel på detaljert informasjon om oversettelsen, tilbake-oversettelsen, valideringen, testingen og revisjonen av spørreskjemaene som var oversatt (19). Vi har synliggjort de ulike trinnene i oversettelsesprosessen og hvilke kulturelle tilpasninger som er gjort, noe som er viktig for at andre kan vurdere den tverrkulturelle validiteten (21).

Det opprinnelige spørreskjemaet (tabell 2 og 3 ) var i utgangspunktet utviklet for overlevering av pasientinformasjon mellom turnusleger på australske sykehus. Det var derfor nødvendig å gjennomføre en validering og kulturell tilpasning slik at spørreskjemaet også kan benyttes blant sykepleiere på norske sykehus. I oversettelsesprosesser vil det i noen tilfeller være enkelte ord eller uttrykk som krever mer kulturell tilpasning enn andre ord (22). 'Handover' kan oversettes til 'overlevering' ved direkte språklig oversettelse. Imidlertid brukes begrepet 'overlevering' ved vaktskiftet innad i en avdeling for å beskrive muntlig rapport ved overlevering av pasientansvar. I vår implementeringsstudie var det intrahospitale overflyttinger mellom sykehusavdelinger som ble studert, og ekspertkomiteen mente derfor at overflytting var et mer beskrivende begrep i denne konteksten. For bruk av skjemaet ved muntlig rapport innad i en avdeling vil imidlertid 'overlevering' være det rette begrepet å benytte.

Det finnes flere prosedyrer man kan benytte ved oversettelse og kulturell tilpasning av et spørreskjema (15,23-26). Vi valgte Beaton (15) sin metode for oversettelse av spørreskjema fordi metoden skisserer en anerkjent tilnærming for frem-og tilbake-oversettelse 
ved å følge seks trinn. Spesielt er den brede sammensetningen av ekspertkomiteen en styrke ved metoden, i tillegg til dialog med utviklerne av originalskjemaet. Beaton skisserer at det skal være minimum to frem-oversettere. Vi har benyttet fire fremoversettere med bakgrunn fra ulike deler av helsetjenesten og fra høyere utdanningsinstitusjoner, noe som medførte at flere nyanser ved språklig og kontekstuell oversettelse ble oppfanget. Ved tilbake-oversettelse benyttet vi to oversettere som var eksperter på selve språket. De kjente ikke til originalversjonen og var ikke orientert om hvilke begreper som ble unders $\varnothing k t$. Dette trinnet skal sikre at oversettelsen gjenspeiler innholdet $\mathrm{i}$ originalversjonen og at en kan oppdage uklare formuleringer i oversettelsene (27). En av oversetterne hadde helsefaglig bakgrunn, noe vi mener er en styrke for å ivareta den kontekstuelle dimensjonen. Dette er også i overenstemmelse med Sousa \& Rojjanasrirat (20) sine funn. De hevder at denne tilnærmingen vil generere to oversatte versjoner som inneholder ord og setninger som dekker både det helsefaglige språket og det vanlige talespråket med dets kulturelle nyanser. Derfor er det å velge velkvalifiserte oversettere nøkkelen til oversettelser av høy kvalitet.

Pretestdeltakere bør rekrutteres fra målpopulasjonen som spørreskjemaet skal brukes på (20), og det er anbefalt at en pretest gjøres før spørreskjemaet prøves ut på målgruppen $(14,15)$.

Pretesten ble utført av åtte nyutdannede intensivsykepleiere for å kartlegge om uttalelsene i spørreskjemaet var forståelige for respondentene, om skjemaet var anvendelig, om det målte det som var tiltenkt og om svaralternativene var i henhold til originalskjemaet. Vi valgte nyutdannede intensivsykepleiere fordi de både har erfaring fra flere typer sengeposter før de startet på sin intensivutdanning, i tillegg til erfaring fra intensivavdelinger under utdanning. Imidlertid kunne en utvidelse av denne gruppen til også å omfatte sykepleiere på sengeposter styrket spørreskjemaets innholdsvaliditet og imøtekommet Beatons anbefalinger om at pretesten ideelt sett bør gjøres på 30-40 personer. Imidlertid angir andre kilder at 10-40 personer er anbefalt i en pretest $(20,28)$. Vi tenker at det viktigste er å få kvalitativt gode tilbakemeldinger på uklarheter $\mathrm{i}$ spørreskjemaet og på spørreskjemaets anvendelighet for målgruppen, slik at dette kan bli rettet opp før bruk. Det anbefales en inter-rater enighet på minimum $80 \%$ mellom pretestdeltakere (20). Imidlertid ble ikke dette regnet ut i denne studien og kan anses som en svakhet ved studien.

Vi har i tabell 1 synliggjort hvilke vurderinger som er lagt til grunn for endringer som er gjort i den norske oversettelsen av spørreskjemaet. Tilbakemeldinger fra utviklerne av spørreskjemaet synliggjorde betydningen av den kulturelle og kontekstuelle dimensjonen når begreper i spørreskjemaer skal oversettes fra et språk til et annet. Ekspertkomiteen diskuterte utviklernes kommentarer på oversettelsen, og kom frem til at oversettelsen hadde det samme meningsinnholdet. Dette illustrerer betydningen av å ha god kjennskap til den kulturelle settingen spørreskjemaet skal benyttes i, og som trinn $4 \mathrm{i}$ oversettelsesprosedyren skal ivareta. Også Sousa fremhever viktigheten av ekspertkomiteens ekspertise både på spørreskjemaets innhold og på konteksten spørreskjemaet skal 
benyttes i, og anbefaler at en ekspertkomite bør bestå av 10 medlemmer (20). Ekspertkomiteen i vår studie bestod av ni personer og var sammensatt av forskere, sykepleiere, undervisere og oversettere, for å bidra til tverrkulturell tilpasning av skjemaet.

En styrke ved spørreskjemaet er at det er variasjon mellom positivt og negativt ladede spørsmål for at ikke respondentene skal komme inn i et modus der de krysser av det samme svaralternativet for flere spørsmål på rad uten å tenke seg om (20). Spørsmål 4 og spørsmål 7 i baselineskjemaet (tabell 2) viser eksempel på et negativt og et positivt ladet spørsmål. Imidlertid fant Utne og medarbeidere i sin oversettelse og pilottesting av spørreskjemaet «Attentional Function Index» at pasienter gav tilbakemelding på at omvendt skåring kan være forvirrende eller oppfattes som en oppmerksomhetstest (29). Vårt spørreskjema inneholder ingen nøytral midtkategori, som for eksempel «vet ikke». Det finnes argumenter både for og imot dette, men forskning gir ikke klare svar på hvorvidt man bør ha en midtkategori eller ikke (30).

De åpne spørsmålene i spørreskjemaet åpner for at sykepleierne får beskrive sine erfaringer med egne ord, og er et viktig supplement til lukkede spørsmål. Vi har modifisert de åpne spørsmålene til en mer nøytral formulering. Formuleringen i originalskjemaet ved baseline var: «Hvordan kan overleveringen forbedres?» Denne formuleringen ble omformulert til: «Ut ifra din erfaring, er det andre forhold ved den muntlige overflyttingsrapporten du vil påpeke, i positiv eller negativ forstand? Beskriv.» I posttestskjemaet var formuleringen i originalskjemaet: «Hvordan har ISBAR forbedret/forverret overleveringen?» Denne formuleringen ble omformulert til «Opplever du at kommunikasjonsverktøyet ISBAR har forbedret eller forverret den muntlige overflyttingsrapporten? Beskriv.» I ettertid ser vi at en bedre formulering for å få respondentene til å gi en mer utfyllende beskrivelse, kunne vært: «Hvordan har ISBAR påvirket den muntlige overflyttingsrapporten?»

\section{Konklusjon}

Tverrkulturell validitet undersøker om en oversatt versjon av et spørreskjema fungerer på samme måte som den originale versjonen. Vi har erfart betydningen av kulturell og kontekstuell tilpasning for at spørreskjemaet skal ha samme meningsinnhold som originalskjemaet. Ekspertkomiteens sammensetning har betydning for ivaretakelse av den tverrkulturelle validiteten ved å diskutere om begrepene i teksten betydde det samme (semantic equivalence), om en må bruke nye ord (idiomatic equivalence; experiential equivalence) og om ordene har ulik mening mellom de to kulturene (conceptual equivalence). Vi mener også det er en fordel at en av tilbake-oversetterne har helsefaglig bakgrunn, for å kunne diskutere de lingvistiske utfordringene når et spørreskjema skal tilpasses en helsefaglig kontekst. Vi har synliggjort de ulike trinnene i oversettelsesprosessen og hvilke kulturelle tilpasninger som er gjort, noe som er viktig for at andre kan vurdere den tverrkulturelle validiteten til spørreskjemaet. Videre gjenstår det å teste spørreskjemaets psykometriske egenskaper. Det anbefales at forskningsstudier synliggjør hvordan de har 
oversatt og krysskulturelt tilpasset nye spørreskjemaer til konteksten det skal benyttes i, og at tidsskrifter tillater at dette blir gjort for å styrke tverrkulturell validitet, som er en av måleegenskapene i COSMIN.

\section{Referanser}

1. Arora V, Farnan J. Patient handoffs [Internett]. 2016 [hentet 09.02.21]. Tilgjengelig fra: https://www. uptodate.com/contents/patient-handoffs.

2. Helsedirektoratet. Årsrapport 2017 [Internett]. Oslo: Meldeordningen for uønskede hendelser i spesialisthelsetjenesten; 2018 [hentet 20.02.21]. Tilgjengelig fra: https://www.helsedirektoratet.no/ rapporter/meldeordningene-arsrapporter/\%C3\%85rsrapport\%202017\%20Meldeordningene.pdf/_/ attachment/inline/31a9b3cc-e5f1-4835-8d6a-dd6be52d36ab:49988oda53042b4e352d83boabb6daec179bf 644/\%C3\%85rsrapport\%202017\%20Meldeordningene.pdf.

3. Spooner AJ, Aitken LM, Chaboyer W. Implementation of an evidence-based practice nursing handover tool in intensive care using the knowledge-to-action framework. Worldviews Evid Based Nurs. 2018;15(2):88-96. https://doi.org/10.1111/wvn.12276.

4. Sluisveld N, Hesselink G, Hoeven J, Westert G, Wollersheim G, Zegers H. Improving clinical handover between intensive care unit and general ward professionals at intensive care unit discharge. Intensive Care Med. 2015;41(4):589-604. https://doi.org/10.1007/s00134-015-3666-8.

5. Finnigan MA, Marshall SD, Flanagan BT. ISBAR for clear communication: one hospital's experience spreading the message. Aust Health Rev. 2010;34(4):400-04. https://doi.org/10.1111/jan.13377.

6. Graan SM, Botti M, Wood B, Redley, B. Nursing handover from ICU to cardiac ward: standardised tools to reduce safety risks. Aust Crit Care. 2016;29(3):165-71. https://doi.org/10.1016/j.aucc. 2015.09.002.

7. Møller TP, Madsen MD, Fuhrmann L, Østergaard D. Postoperative handover: characteristics and considerations on improvement: a systematic review. Eur J Anaesthesiol. 2013;30(5), 229-42. https://doi.org/10.1097/EJA.obo13e32835d8520.

8. Ong M-S, BiomedE M, E. A systematic review of failures in handoff communication during intrahospital transfers. Jt Comm J Qual Patient Saf. 2011;37(6):274-84. https://doi.org/10.1016/S15537250(11)37035-3.

9. Moi EB, Söderhamn U, Marthinsen GN, Flateland SM. The ISBAR tool leads to conscious, structured communication by healthcare personnel. Sykepleien Forskning. 2019;14:1-9. https://doi.org/10.4220/ Sykepleienf.2019.74699.

10. World Health Organization [Internett]. Communication during patient-handover. 2007 [hentet 12.03.21]. Tilgjengelig fra: http://www.who.int/patientsafety/solutions/patientsafety/PS-Solution3.pdf.

11. Helsedirektoratet. Tidlig oppdagelse og rask respons ved forverret somatisk tilstand-nasjonale faglige råd. 2020 [hentet 25.03.21]. Tilgjengelig fra: https://www.helsedirektoratet.no/faglige-rad/tidligoppdagelse-og-rask-respons-ved-forverret-somatisk-tilstand/om-de-faglige-radene-del-av-i-tryggehender-24-7.

12. Tangvik LS, Kinn-Mikalsen MA, Johnsgaard T, Reime MH. Observasjonsskjema for måling av ISBAR. Inspira. 2020(1):5-13. https://hdl.handle.net/11250/2736133.

13. Mokkink LB, Terwee CB, Knol DL, Stratford PW, Alonso J, Patrick DL, et al. The COSMIN checklist for evaluating the methodological quality of studies on measurement properties: a clarification of its content. BMC Med Res Methodol. 2010;10:22. https://doi.org/10.1186/1471-2288-10-22.

14. Polit DF, Beck CT. Nursing research: generating and assessing evidence for nursing practice. 10. utg. Philadelphia: Wolters Kluwer Health; 2017. 
15. Beaton DE, Bombardier C, Guillemin F, Ferraz MB. Guidelines for the process of cross-cultural adaptation of self-report measures. Spine. 2000;25(24):3186-91. https://doi.org/10.1097/00007632200012150-00014.

16. Thompson JE, Collett LW, Langbart MJ, Purcell NJ, Boyd SM, Yuminaga Y, et al. Using the ISBAR handover tool in junior medical officer handover: a study in an Australian tertiary hospital. Postgrad Med J. 2011;87(1027):340-4. https://doi.org/10.1136/pgmj.2010.105569.

17. Enger R, Andershed B. Nurses' experience of the transfer of ICU patients to general wards: a great responsibility and a huge challenge. J Clin Nurs. 2018;27(1-2):e186-e94. https://doi.org/10.1111/ jocn.13911.

18. Malterud K. Kvalitative forskningsmetoder for medisin og helsefag. 4. utg. Oslo: Universitetsforlaget; 2017.

19. Maneesriwongul W, Dixon JK. Instrument translation process: a methods review. J Adv Nurs. 2004;48(2):175-86. https://doi.org/10.1111/j.1365-2648.2004.03185.x.

20. Sousa VD, Rojjanasrirat W. Translation, adaptation and validation of instruments or scales for use in cross-cultural health care research: a clear and user-friendly guideline. J Eval Clin Prac. 2011;17(2): 268-74. https://doi.org/10.1111/j.1365-2753.2010.01434.x.

21. Johnson TP. Methods and frameworks for crosscultural measurement. Med Care. 2006;44(11 Suppl 3): 17-20. https://doi.org/10.1097/01.mlr.0000245424.16482.f1.

22. Van Widenfelt B, Treffers M, Beurs P, Siebelink D, Koudijs A. Translation and cross-cultural adaptation of assessment instruments used in psychological research with children and families. Clin Child Fam Psychol Rev. 2005;8(2):135-47. https://doi.org/10.1007/s10567-005-4752-1.

23. Verdens helseorganisasjon (WHO). Process of translation and adaptation of instruments [Internett]. 2016 [hentet 12.03.21]. Tilgjengelig fra: https://www.coursehero.com/file/30372721/WHO-Process-oftranslation-and-adaptation-of-instrumentspdf/.

24. Borsa JC, Damasio BF, Bandeira DR. Cross-cultural adaptation and validation of psychological instruments: some considerations. Paidéia. 2012;22(53):423-32. https://doi.org/10.1590/So103$863 \times 2012000300014$.

25. Chen HY, Boore JR. Translation and back-translation in qualitative nursing research: methodological review. J Clin Nurs. 2010;19(1-2):234-9. https://doi.org/10.1111/j.1365-2702.2009.

26. Guillemin F, Bombardier C, Beaton D. Cross-cultural adaptation of health-related quality of life measures: literature review and proposed guidelines. J Clin Epidemiol. 1993;46(12):1417-32. https://doi. org/10.1016/0895-4356(93)90142-N.

27. Karlgren K, Lakkala M, Toom A, Ilomäki L, Lahti-Nuuttila P, Muukkonen H. Assessing the learning of knowledge work competence in higher education-cross-cultural translation and adaptation of the Collaborative Knowledge Practices Questionnaire. Res Pap Educ. 2020;35(1):8-22. https://doi.org/ 10.1080/02671522.2019.1677752.

28. Sousa VD, Hartman SW, Miller EH, Carroll MA. New measures of diabetes self-care agency, diabetes self-efficacy, and diabetes self-management for insulin-treated individuals with type 2 diabetes. J Clin Nurs. 2009;18(9):1305-12. https://doi.org/10.1111/j.1365-2702.2008.02729.x.

29. Utne I, Grov EK, Kjerland LE, Rønning M, Rodrigues-Aranda C, Rasmussen HL, et al. Oversettelse og kulturell tilpasning av Attentional Function Index (AFI). Sykepleien Forskning. 2017;12(64646): (e-64646). https://doi.org/10.4220/Sykepleienf.2017.64646.

30. Jacobsen DI. Hvordan gjennomføre unders $\varnothing$ kelser? Innføring i samfunnsvitenskapelig metode. Oslo: Cappelen Damm Akademisk; 2015. 